Western University

Scholarship@Western

Aboriginal Policy Research Consortium International (APRCi)

$12-19-2008$

\title{
Aboriginal Interpretation in Australian Wildlife Tourism
}

Heather Zeppel

James Cook University

Sue Muloin

James Cook University

Follow this and additional works at: https://ir.lib.uwo.ca/aprci

Part of the Place and Environment Commons, Sociology of Culture Commons, and the Tourism Commons

Citation of this paper:

Zeppel, Heather and Muloin, Sue, "Aboriginal Interpretation in Australian Wildlife Tourism" (2008). Aboriginal Policy Research Consortium International (APRCi). 431.

https://ir.lib.uwo.ca/aprci/431 
This article was downloaded by: [University of Western Ontario]

On: 07 December 2012, At: 10:44

Publisher: Routledge

Informa Ltd Registered in England and Wales Registered Number: 1072954

Registered office: Mortimer House, 37-41 Mortimer Street, London W1T 3J H, UK

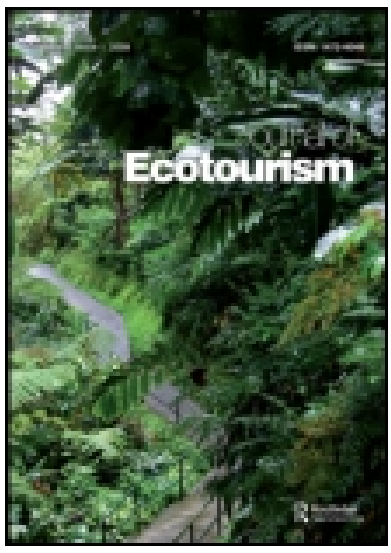

\section{J ournal of Ecotourism}

Publication details, including instructions for authors and subscription information: http:// www.tandfonline.com/loi/ reco20

\section{Aboriginal Interpretation in Australian Wildlife Tourism}

Heather Zeppel ${ }^{a} \&$ Sue Muloin ${ }^{a}$

a J ames Cook University, Cairns, Australia

Version of record first published: 19 Dec 2008.

To cite this article: Heather Zeppel \& Sue Muloin (2008): Aboriginal Interpretation in Australian Wildlife Tourism, J ournal of Ecotourism, 7:2-3, 116-136

To link to this article: http:// dx.doi.org/ 10.1080/ 14724040802140493

\section{PLEASE SCROLL DOWN FOR ARTICLE}

Full terms and conditions of use: http://www.tandfonline.com/page/terms-andconditions

This article may be used for research, teaching, and private study purposes. Any substantial or systematic reproduction, redistribution, reselling, loan, sub-licensing, systematic supply, or distribution in any form to anyone is expressly forbidden.

The publisher does not give any warranty express or implied or make any representation that the contents will be complete or accurate or up to date. The accuracy of any instructions, formulae, and drug doses should be independently verified with primary sources. The publisher shall not be liable for any loss, actions, claims, proceedings, demand, or costs or damages whatsoever or howsoever caused arising directly or indirectly in connection with or arising out of the use of this material. 


\title{
Aboriginal Interpretation in Australian Wildlife Tourism
}

\author{
Heather Zeppel and Sue Muloin \\ James Cook University, Cairns, Australia
}

This paper evaluates Aboriginal cultural interpretation at wildlife attractions and on wildlife tours in Australia. The sites included 14 wildlife parks or zoos; three Aboriginal-owned emu or crocodile farms; and 16 wildlife tours, river cruises or resorts with Indigenous interpretation of wildlife. Telephone interviews were conducted with 35 managers (nine Indigenous) and 26 Indigenous staff at wildlife attractions that included verbal or written Aboriginal wildlife interpretation. The Indigenous guides verbally presented both traditional uses and personal stories about Australian wildlife followed by Aboriginal 'Dreaming' or creation stories about totemic animal species. Non-Indigenous staff explained traditional Aboriginal uses of wildlife followed by biological facts and species information. The responses in this study thus highlight cultural differences in animal attitudes and approaches to wildlife use or interpretation. According to staff, tourists benefit from the inclusion of Aboriginal interpretation at wildlife sites by broadening their mind, dispelling myths, learning/education about Aboriginal cultures, novelty and excitement for visitors, increasing cultural awareness and developing more positive attitudes towards Indigenous people. Some guidelines for wildlife attractions and tours to develop and present Aboriginal cultural interpretation of Australian wildlife are also identified.

doi: $10.2167 /$ joe-226.0

Keywords: wildlife tourism, Australia, Indigenous cultures, wildlife interpretation, zoos, animal attitudes

\section{Introduction}

This paper evaluates Aboriginal cultural interpretation of wildlife featured at 17 captive wildlife attractions and on 16 wildlife tours across mainland Australia. This includes the involvement of Indigenous people as tour guides and wildlife keepers as well as on-site interpretive signs, displays or brochures presenting Indigenous cultural perspectives of Australian wildlife. This study reviews the verbal presentation of Indigenous culture and wildlife knowledge, and the tourist benefits of providing Indigenous cultural interpretation at wildlife tourism sites. Guidelines to further enhance and develop Indigenous cultural interpretation of wildlife are also presented. This paper first describes Indigenous connections with Australian wildlife and Indigenous wildlife tourism; then reviews wildlife interpretation in zoos linked with changing human attitudes towards animals. It then evaluates the content, presentation and tourist benefits of Indigenous cultural interpretation of wildlife at key wildlife sites in Australia, based on verbal comments made by both managers and Indigenous staff. Cultural differences in animal attitudes and wildlife interpretation are 
highlighted in these responses. Hence, key issues for wildlife sites to develop and present Indigenous cultural interpretation of wildlife are also discussed.

\section{Aboriginal Relationships with Australian Wildlife}

The relationship between Indigenous peoples and Australian wildlife includes ongoing traditional cultural and spiritual dimensions, the use of wildlife for food and other sustenance and more recent commercial uses (Adams, 1996; AWMS, 2004; Davies, 1999), including wildlife farms and wildlife tourism. Traditional Indigenous links with Australian wildlife include the following:

- subsistence resource (e.g. food or 'bush tucker', clothing, artefacts, medicinal use and wildlife fire ecology);

- companion animals (e.g. wildlife pets such as dingos, kangaroos, wallabies and birds);

- hunting aids (e.g. dingos hunting kangaroos; dolphins driving fish into nets/shore);

- 'Dreaming' or creation stories about wildlife (i.e. fauna species as ancestral creative beings);

- totemic significance (i.e. spiritual links with wildlife species; taboos on hunting or eating totemic animals; wildlife refuge areas; and imitative wildlife dances); and

- ceremonial significance (e.g. rituals to maintain or increase wildlife species).

Traditional relationships between Indigenous peoples and wildlife are underpinned by their spiritual affiliations to 'country', with wildlife being an integral component (Davies et al., 1999). Spiritual affiliations accord both rights and responsibilities, including custodial responsibilities for keeping the land healthy and its species abundant. In traditional Australian Indigenous cultures, rights to hunt and gather natural resources like wildlife are seen as an integral part of 'caring for country.' Often, there is a strong link between subsistence, ceremonial and ritual use of wildlife by Indigenous peoples (Yibarbuk, 1998). For example, in Arnhem Land, crocodiles are respected as important totemic beings, and senior elders have rejected the hunting of adult crocodiles for their skin and meat. In contrast, crocodile eggs are harvested by Aboriginal rangers and sold to farms as a sustainable economic use of wildlife resources (Langton, 1998).

Contemporary Indigenous relationships with Australian wildlife, then, include new scientific, recreational or commercial dimensions. This includes Indigenous involvement in new wildlife initiatives such as:

- wildlife research on Indigenous land (e.g. fauna surveys and research on endangered species);

- wildlife management initiatives on Indigenous land (e.g. Arnhem Land and Cape York);

- commercial utilisation of wildlife (e.g. emu and crocodile farms; commercial fishing; safari hunting; sport fishing; artefacts; and tourism); and

- recreational use of wildlife (e.g. lizard racing; juvenile crocodile racing).

Indigenous environmental knowledge includes information on wild animal foods or 'bush tucker'; relationships between different species and between animals and their environment; and details of animal behaviour (Baker, 1996). 
However, little is known by the general Australian or international community about traditional or contemporary Indigenous relationships with wildlife. Hence, wildlife tourism and Indigenous cultural interpretation at wildlife sites offer an opportunity to communicate Indigenous knowledge, use and understanding of Australian fauna to the wider community.

\section{Indigenous Wildlife Tourism}

There are several recent reports on contemporary Indigenous uses of wildlife in Australia, some of which include coverage of the use of wildlife in tourism (Bomford \& Caughley, 1996; Commonwealth of Australia, 1998; Davies et al., 1999; Meek \& O’Brien, 1992; Ramsay, 1994; Wilson et al., 1992; Wilson \& Tisdell, 2001). These include Indigenous wildlife harvesting or farming ventures and safari hunting on Aboriginal lands. Some reports indicate that the combination of Indigenous tourism and wildlife tourism may have considerable growth potential on Aboriginal lands in northern Australia (Palmer, 2001; Pitcher et al., 1999). However, there has been little research on the nature and extent of Indigenous involvement in wildlife tourism or on Indigenous cultural interpretation of wildlife (Muloin et al., 2001; Schmiechen, 2006; Zeppel \& Muloin, 2005; Zeppel et al., 2003). Indigenous interpretations of nature and wildlife are important for the maturing ecotourism market in Australia in experiencing cultural links with the environment (Department of Industry, Tourism \& Resources, 2004). This gap in the research literature provided the main rationale for the present study of Indigenous interpretation of wildlife at key tourism sites in Australia. This study on Indigenous wildlife tourism was conducted in 1999-2000 and was funded by the CRC for Sustainable Tourism.

Indigenous wildlife tourism was defined in this study as 'wildlife attractions or tours involving Indigenous people and/or Indigenous knowledge (i.e. interpretation) of living wildlife' (Muloin et al., 2001: 12). The interpretation objectives of this pilot study of wildlife tourism in Australia were to: 'Evaluate the ways in which Indigenous cultures and Indigenous knowledge of native fauna are presented in wildlife tourism and to provide recommendations to enhance the presentation of Indigenous wildlife knowledge at Australian wildlife attractions' (Muloin et al., 2001: 10).

In this study, the wildlife attractions or tours with Indigenous input were required to meet one or more of the following criteria:

- employ Indigenous people as guides, interpreters or wildlife keepers;

- incorporate Indigenous content into their wildlife tours or educational programmes;

- regularly consult with Indigenous people on wildlife or cultural issues; and/or

- Indigenous owned or part-owned wildlife attractions (e.g. emu and crocodile farms).

The focus was on wildlife attractions or tours that included an Indigenous cultural component (i.e. Indigenous staff, guided tours or interpretive signs). Based on these criteria, the study included 33 wildlife attractions or tours across Australia that included Indigenous staff and/or cultural interpretation (see Table 1). This study found there were 15 Indigenous staff employed at the 
Table 1 Australian wildlife attractions and tours with Aboriginal cultural interpretation

\begin{tabular}{||l|l||}
\hline \hline Captive Wildlife Attractions & \multicolumn{1}{|c||}{ Wildlife Tours, Cruises and Resorts } \\
\hline Taronga Zoo, NSW & Australian Wildlife Tours, ACT \\
\hline Western Plains Zoo, NSW & Harry Nanya Tours, NSW \\
\hline Adelaide Zoo, SA & Yalata Land Management, SA \\
\hline Cleland Wildlife Park, SA & Darngku Heritage Cruises, WA \\
\hline Werribee Open Range Zoo, VIC & Eco Beach Retreat, WA \\
\hline Healesville Sanctuary, VIC & Goombaning Corporation Boat Charter, WA \\
\hline Kurrawang Emu Farm, WA & Kimberley Bushwalks \& Camel Safaris, WA \\
\hline Alice Springs Desert Park, NT & Kooljaman at Cape Leveque, WA \\
\hline Territory Wildlife Park, NT & Nature's Hideaway, WA \\
\hline Crocodylus Park, NT & One Arm Point Aboriginal Community, WA \\
\hline Currumbin Sanctuary, QLD & Bawinanga Safaris, NT \\
\hline David Fleay Wildlife Park, QLD & Birds, Bees, Trees \& Things, NT \\
\hline Wild World Zoo, QLD & Guluyambi Cultural Cruise, NT \\
\hline Billabong Sanctuary, QLD & Nitmiluk Cruises, NT \\
\hline Reef HQ Aquarium, QLD & Yellow Water Cruises, NT \\
\hline Cherbourg Emu Farm, QLD & Pajinka Wilderness Lodge, QLD \\
\hline Edward River Crocodile Farm, QLD & \\
\hline
\end{tabular}

selected state-owned zoos and wildlife parks, and 30 to 50 Indigenous staff employed by nature tour operators and Indigenous-owned wildlife farms, resorts and cruises in Australia. The Alice Springs Desert Park (ASDP) has four out of seven guide positions for local Arrernte Aboriginal people and species identification signs use names of the Central Arrernte local Aboriginal language group along with the common and taxonomic names of wildlife (ASDP, 2001, 2004; Clarkson, 1999).

\section{Wildlife Interpretation in Zoos}

Previous studies of wildlife interpretation in zoos focus on general principles for interpreting captive wildlife displays through exhibit design, animal behaviours, signs and keeper talks: 'Interpretation involves the whole animal and its exhibit, as well as the relevant graphics, signs, booklets, keeper talks and guides' (Woods, 1998: 29). This includes the pictorial and written content of interpretive signs providing information about wildlife and the presentation of animal exhibits in a more naturalistic manner with recreated habitats, mixed species 
and open-range settings (Tribe, 2001). Other studies have compared visitor responses to zoo interpretation at traditional wildlife exhibits and more interactive interpretive talks with animal shows and keepers handling wildlife (Broad \& Weiler, 1998; Povey \& Rios, 2002; Smith \& Broad, 2006; Swanagan, 2000) (see Table 2). Keeper talks and interaction with wildlife, rather than static signs and enclosures, increased visitor attention, learning and support for wildlife conservation. For example, keeper presentations rather than signs at a colobus monkey exhibit in Disney's Animal Kingdom (USA) increased visitor knowledge about conservation and the impact of the bushmeat trade in Africa on wildlife (Lehnhardt et al., 2004). Visiting zoos is largely a social experience with family or friends, with visitors seeking recreation and entertainment along with education about wildlife or environmental issues (Mason, 2000; Shackley, 1996). These motives for zoo visitation influence the effectiveness and learning outcomes of wildlife interpretation (Woods, 1998). Some zoos in Europe now

Table 2 Wildlife interpretation at zoo exhibits

\begin{tabular}{|c|c|c|c|c|}
\hline Author(s) & Zoo & $\begin{array}{l}\text { Animal } \\
\text { exhibit }\end{array}$ & Interpretation & Visitor study \\
\hline $\begin{array}{l}\text { Smith \& } \\
\text { Broad, } \\
2006\end{array}$ & $\begin{array}{c}\text { Melbourne } \\
\text { Zoo Vic, } \\
\text { Australia }\end{array}$ & $\begin{array}{l}\text { Asian } \\
\text { elephant }\end{array}$ & $\begin{array}{l}\text { Interpretive signs } \\
\text { Keeper talks }\end{array}$ & $\begin{array}{l}\text { Visitor interviews } \\
\text { Timing visitors }\end{array}$ \\
\hline $\begin{array}{l}\text { Lehnhardt } \\
\text { et al., } \\
2004\end{array}$ & $\begin{array}{l}\text { Disney's } \\
\text { Animal } \\
\text { Kingdom, } \\
\text { USA }\end{array}$ & $\begin{array}{l}\text { Colobus } \\
\text { monkey }\end{array}$ & $\begin{array}{l}\text { Keeper talk Signs } \\
\text { and graphics } \\
\text { Feeding monkeys }\end{array}$ & $\begin{array}{l}\text { Visitor interviews } \\
\text { Exhibit/signs } \\
\text { survey } \\
\text { Keeper talk } \\
\text { survey }\end{array}$ \\
\hline $\begin{array}{l}\text { Povey and } \\
\text { Rios, } \\
2002\end{array}$ & $\begin{array}{l}\text { Zoo Atlanta } \\
\text { Georgia, } \\
\text { USA }\end{array}$ & $\begin{array}{l}\text { African } \\
\text { elephant }\end{array}$ & $\begin{array}{l}\text { Elephant Show } \\
\text { Bio-fact cart } \\
\text { (artefacts) } \\
\text { Graphics (signs) }\end{array}$ & $\begin{array}{l}\text { Exit survey } \\
\text { Petition } \\
\text { Solicitation cards }\end{array}$ \\
\hline $\begin{array}{l}\text { Swanagan, } \\
2000\end{array}$ & $\begin{array}{l}\text { Point Defiance } \\
\text { Zoo } \\
\text { Washington, } \\
\text { USA }\end{array}$ & $\begin{array}{l}\text { Clouded } \\
\text { leopard }\end{array}$ & $\begin{array}{l}\text { Enclosure and } \\
\text { signs } \\
\text { Handler walks \& } \\
\text { talks } \\
\text { Visitor questions }\end{array}$ & $\begin{array}{l}\text { Visitor survey } \\
\text { Timing visitors } \\
\text { Observation study }\end{array}$ \\
\hline \multirow[t]{2}{*}{$\begin{array}{l}\text { Broad and } \\
\text { Weiler, } \\
1998\end{array}$} & $\begin{array}{l}\text { Dreamworld } \\
\text { Park Tiger } \\
\text { Island, Qld } \\
\text { Australia }\end{array}$ & $\begin{array}{l}6 \text { Bengal } \\
\text { tigers }\end{array}$ & $\begin{array}{l}\text { Handlers swim } \\
\text { and play with } \\
\text { tigers } \\
\text { Handler talks } \\
\text { Brochure, displays } \\
\text { Info kit, tiger photo }\end{array}$ & $\begin{array}{l}\text { Content analysis } \\
\quad \text { (written } \\
\text { material) } \\
\text { Observation } \\
\text { Interviews } \\
\text { Timing visitors }\end{array}$ \\
\hline & $\begin{array}{l}\text { Western Plains } \\
\text { Zoo Dubbo, } \\
\text { NSW } \\
\text { Australia }\end{array}$ & $\begin{array}{l}1 \text { Bengal } \\
\text { tiger }\end{array}$ & $\begin{array}{l}\text { Interpretive sign } \\
\text { Keeper talk } \\
\quad \text { (weekends) } \\
\text { Tiger feeding } \\
\text { Touch table } \\
\text { (artefacts) }\end{array}$ & $\begin{array}{l}\text { Timing visitors } \\
\text { Analysis (talk) } \\
\text { Observation }\end{array}$ \\
\hline
\end{tabular}


interpret cultural aspects of wildlife conservation in Mongolia, Nepal and Africa (Slotta-Bachmayr, 2003); bison and Lakota Native American culture (Peters, 2002); and personal stories about wildlife by zookeepers (Podhorska, 2004). Through research, signs and exhibits, zoos are also linking captive wildlife displays to in situ or on-site conservation programmes for endangered wildlife species. At Australian zoos, these conservation initiatives often focus on scientific research or local community development programmes for endangered wildlife species such as Asian elephants and Bengal tigers in South Asia and tree kangaroos in Papua New Guinea (Aughterson, 2004; Tribe, 2004). However, there is minimal interpretation at Australian zoos and wildlife parks about Indigenous wildlife knowledge or Aboriginal involvement in conserving endangered native wildlife.

\section{Animal Attitudes and Wildlife Interpretation}

This paper suggests there are cultural differences in animal attitudes and approaches to wildlife use or interpretation. The conceptual framework applied to this review of Indigenous wildlife interpretation is Kellert's study of animal attitudes in the USA that identified 10 main beliefs regarding wild or domestic animals (Kellert, 1989, 1993). These attitudes covered ethical, emotional, scientific and material values of animals linked with socio-demographic characteristics and nature-based activities. Hills (1993) also identified similar animal attitudes based on instrumental self-interest, empathy or identification, and people's beliefs and values about the status and nature of animals. The five animal attitudes most associated with wildlife tourism are: moralistic, utilitarian, aesthetic, ecologistic and scientistic/knowledge of animals (see Table 3). These animal attitudes are reflected in approaches to wildlife exhibits, nature conservation and wildlife interpretation in tourism settings. This includes improved animal welfare, 'natural' wildlife behaviours, personal stories about wildlife and cultural aspects of wildlife conservation, including religion and the views of Indigenous people. However, Hopgood (2000) notes that social and cultural themes are little addressed in zoo education. This includes different cultural perceptions of nature and wildlife, and impacts on indigenous peoples (Green, 1993; Lawrence, 1993; Ris, 1994). There has been some research on Indigenous interpretation of cultural landscapes (Carr, 2004), but there are few existing studies comparing indigenous and non-indigenous animal attitudes and the messages in wildlife interpretation about the cultural importance of wild animals.

\section{Research Methodology}

Information in this study was derived from structured interviews with key people involved in Indigenous wildlife tourism. Telephone interviews were conducted with 35 managerial staff (nine were Indigenous) and 26 Indigenous staff members (eight of whom were also managers or owners) at 33 Indigenous wildlife attractions or tours across Australia. Hence, approximately half of the people interviewed in this study were Indigenous (i.e. 27 out of 53 respondents). In this study, 'manager' refers to staff interviewed at a supervisory or coordinator level that had responsibility or interest in Indigenous involvement as well as owners of the wildlife operations. The interview questions sought 
Table 3 Animal attitudes in wildlife interpretation

\begin{tabular}{||l|l|l||}
\hline Animal attitude & \multicolumn{1}{|c|}{ Description of attitude } & \multicolumn{1}{c|}{$\begin{array}{c}\text { Wildlife } \\
\text { interpretation }\end{array}$} \\
\hline Moralistic & $\begin{array}{l}\text { Ethical treatment and fundamental equality } \\
\text { of all animals; fundamental spiritual } \\
\text { meaning, order and harmony in nature, } \\
\text { often associated with the views of } \\
\text { Indigenous people }\end{array}$ & $\begin{array}{l}\text { Conservation } \\
\text { Cultural values }\end{array}$ \\
\hline Utilitarian & $\begin{array}{l}\text { Assess animals on basis of their practical } \\
\text { and material value and assumes animals } \\
\text { serve some human purpose or for } \\
\text { personal gain }\end{array}$ & $\begin{array}{c}\text { Hunting, income, } \\
\text { food, fashion }\end{array}$ \\
\hline Aesthetic & $\begin{array}{l}\text { Attractiveness or symbolic significance of } \\
\text { animals, artistic appeal and allegorical } \\
\text { bearers of a message aesthetic or symbolic }\end{array}$ & $\begin{array}{c}\text { Artwork, photos, } \\
\text { totemic/religious }\end{array}$ \\
\hline Ecologistic & $\begin{array}{c}\text { Conceptual understanding and concern for } \\
\text { environment as a system and wildlife } \\
\text { species as barometers of natural system }\end{array}$ & $\begin{array}{c}\text { Habitat/ecology, } \\
\text { endangered } \\
\text { species }\end{array}$ \\
\hline Scientistic & $\begin{array}{l}\text { Focus on biological and physical character- } \\
\text { istics of animals and value animals as } \\
\text { objects of study, curiosity and observation }\end{array}$ & $\begin{array}{c}\text { Biology, behaviour, } \\
\text { wildlife research }\end{array}$ \\
\hline
\end{tabular}

Other animal attitudes are: neutralistic, humanistic, naturalistic, doministic \& negativistic

Source: Based on Kellert $(1989,1993)$

information on the wildlife tourism operation and the work roles of the respondents along with the type and extent of Indigenous interpretive information about wildlife provided at the attraction. These comments about Aboriginal cultural interpretation of wildlife are presented in Tables 4-6, with responses by Indigenous staff and Indigenous or non-Indigenous managers indicated in the tables. The comments in the tables are organised according to key issues for Aboriginal cultural interpretation of wildlife, as suggested by the people interviewed in this study. The survey also asked the respondents' views on tourist benefits from experiencing Australian wildlife through an Aboriginal cultural perspective. These responses included both captive attractions and free-ranging wildlife sites with an Aboriginal cultural element.

\section{Indigenous Wildlife Interpretation: Results}

This section summarises the interview findings on the nature and type of Indigenous wildlife interpretation currently presented at Australian wildlife attractions or tours participating in this study. In particular, it focuses on how Indigenous cultural knowledge and use of Australian wildlife is incorporated in the wildlife displays or tours at each attraction. Guided tours and wildlife feeding talks (14\%) represented the most common form of Indigenous wildlife interpretation provided at the study sites; followed by a brochure advertising the wildlife attraction (11.6\%); displays $(9.3 \%)$; information sheets or maps 
Table 4 Verbal interpretive information about Australian wildlife

\begin{tabular}{|c|c|c|c|}
\hline $\begin{array}{l}\text { Interpretive } \\
\text { information }\end{array}$ & $\begin{array}{l}\text { Manager } \\
(\%)\end{array}$ & $\begin{array}{l}\text { Indigenous } \\
\text { Staff }(\%)\end{array}$ & Examples \\
\hline \multirow{2}{*}{$\begin{array}{l}\text { Biological facts and } \\
\text { species } \\
\text { information }\end{array}$} & \multirow[t]{2}{*}{14.4} & \multirow[t]{2}{*}{13.6} & $\begin{array}{l}\text { 'A little bit; mostly identification and } \\
\text { where they live.' [Indigenous staff] }\end{array}$ \\
\hline & & & $\begin{array}{l}\text { 'This is the main focus. The } \\
\text { information provided to tourists } \\
\text { is put into a context: Talk about } \\
\text { habitats and the role of species; } \\
\text { how they interact with humans, } \\
\text { especially tourists.' [non- } \\
\text { Indigenous manager] }\end{array}$ \\
\hline \multirow[t]{2}{*}{$\begin{array}{l}\text { Aboriginal } \\
\text { Dreaming or } \\
\text { creation stories }\end{array}$} & \multirow[t]{2}{*}{10.9} & \multirow[t]{2}{*}{14.8} & $\begin{array}{l}\text { 'How Aboriginals respect the } \\
\text { animals and make use of them } \\
\text { (e.g. kangaroo meat to eat; skin } \\
\text { for clothes; tooth for needle; bone } \\
\text { for utensil), and ask permission } \\
\text { to use them by the Great Spirit.' } \\
\text { [Indigenous staff] }\end{array}$ \\
\hline & & & $\begin{array}{l}\text { 'Not a lot because some stories they } \\
\text { are not allowed to mention to the } \\
\text { tourists. All guides talk about } \\
\text { Dreamtime, even if they are not } \\
\text { Aboriginal, and some are related } \\
\text { to wildlife.' [non-Indigenous } \\
\text { manager] }\end{array}$ \\
\hline \multirow[t]{2}{*}{$\begin{array}{l}\text { Traditional } \\
\text { Indigenous use of } \\
\text { wildlife }\end{array}$} & \multirow[t]{2}{*}{14.9} & \multirow[t]{2}{*}{17.3} & $\begin{array}{l}\text { ‘I talk about traditional hunting, } \\
\text { but only a little bit and } \\
\text { usually when tourists ask.' } \\
\text { [Indigenous staff] }\end{array}$ \\
\hline & & & $\begin{array}{l}\text { 'kangaroo, plants and how to cook } \\
\text { animals; traditional hunting.' } \\
\text { [Indigenous manager] }\end{array}$ \\
\hline \multirow[t]{2}{*}{$\begin{array}{l}\text { Contemporary } \\
\text { Indigenous } \\
\text { wildlife use }\end{array}$} & \multirow[t]{2}{*}{10.0} & \multirow[t]{2}{*}{6.2} & $\begin{array}{l}\text { 'Only if they ask. I still go out and } \\
\text { shoot a kangaroo and either cook } \\
\text { it traditionally or freeze it for } \\
\text { later.' [Indigenous staff] }\end{array}$ \\
\hline & & & $\begin{array}{l}\text { 'A little bit about how they burn } \\
\text { today; what the boys do on the } \\
\text { weekend; and how they hunt } \\
\text { today (e.g. use guns now rather } \\
\text { than spears and boomerangs).' } \\
\text { [Indigenous manager] }\end{array}$ \\
\hline $\begin{array}{l}\text { Contemporary } \\
\text { Indigenous } \\
\text { wildlife } \\
\text { management }\end{array}$ & 10.9 & 7.4 & $\begin{array}{l}\text { 'Feral animals and endangered } \\
\text { breeding program.' } \\
\text { [Indigenous staff] }\end{array}$ \\
\hline
\end{tabular}


Table 4 (Continued)

\begin{tabular}{|c|c|c|c|}
\hline $\begin{array}{l}\text { Interpretive } \\
\text { information }\end{array}$ & $\begin{array}{l}\text { Manager } \\
(\%)\end{array}$ & $\begin{array}{l}\text { Indigenous } \\
\text { Staff }(\%)\end{array}$ & Examples \\
\hline & & & $\begin{array}{l}\text { 'Management of introduced species.' } \\
\text { [non-Indigenous manager] }\end{array}$ \\
\hline \multirow{2}{*}{$\begin{array}{l}\text { Personal and/or } \\
\text { family's involve- } \\
\text { ment with wildlife }\end{array}$} & \multirow[t]{2}{*}{12.9} & \multirow[t]{2}{*}{17.3} & $\begin{array}{l}\text { 'Totems and personal experiences.' } \\
\text { [Indigenous staff] }\end{array}$ \\
\hline & & & $\begin{array}{l}\text { 'Significance culturally; in some clan } \\
\text { groups, won't eat emus as part of } \\
\text { kinship.' [Indigenous manager] }\end{array}$ \\
\hline \multirow[t]{2}{*}{$\begin{array}{l}\text { Understanding } \\
\text { ecology/ } \\
\text { inter-relationships }\end{array}$} & \multirow[t]{2}{*}{11.9} & \multirow[t]{2}{*}{11.1} & $\begin{array}{l}\text { 'Not in the Australian enclosure, } \\
\text { but in the African one in relation } \\
\text { to the gene pool; exchange } \\
\text { program; poaching; etc.' } \\
\text { [Indigenous staff] }\end{array}$ \\
\hline & & & $\begin{array}{l}\text { 'Impacts of buffalos; valuable } \\
\text { resources.' [non-Indigenous } \\
\text { manager] }\end{array}$ \\
\hline \multirow[t]{2}{*}{$\begin{array}{l}\text { Explicit conservation } \\
\text { message }\end{array}$} & \multirow[t]{2}{*}{11.4} & \multirow[t]{2}{*}{12.3} & $\begin{array}{l}\text { 'Earth is my mother so must respect } \\
\text { her and not throw rubbish as this } \\
\text { is disrespectful. We don't own her, } \\
\text { she owns us.' [Indigenous staff] }\end{array}$ \\
\hline & & & $\begin{array}{l}\text { 'Not preachy, but there is a strong } \\
\text { conservation message in the } \\
\text { presentation focusing on } \\
\text { empowerment.' [non-Indigenous } \\
\text { manager] }\end{array}$ \\
\hline
\end{tabular}

about the site and the wildlife exhibits (9.3\%); and permanent signage about wildlife $(8.8 \%)$. All of this interpretive material included some Indigenous content about wildlife. The 'other' types of wildlife interpretation were sculptures of animals; Aboriginal dance performances with dancers imitating native wildlife (e.g. kangaroo and emu); and 'roving' staff talking with tourists. Overall, 30 sites (91\%) incorporated some type of Indigenous interpretation of Australian wildlife.

However, this Indigenous cultural interpretation was often minimal at wildlife parks and zoos (e.g. Aboriginal artwork, signs and school programmes). The information was mostly interpreted verbally through Dreamtime stories about wildlife species; dance (e.g. Currumbin Sanctuary and Wild World Zoo, QLD); singing (e.g. Taronga Zoo Education Program, NSW), and by the use of traditional Aboriginal artefacts in interpretive talks (e.g. David Fleay Wildlife Park, QLD; and Alice Springs Desert Park, NT). One staff member indicated that the cultural interpretation he provides is also achieved through his artwork. The cultural information was usually presented to tourists in an informal manner while walking around the site, on a group tour and/or when tourists ask specific questions. The Indigenous guides interpret wildlife (e.g. identifying 
Table 5 How wildlife can help tourists understand Aboriginal cultures

\begin{tabular}{|c|c|}
\hline $\begin{array}{l}\text { Wildlife \& Indigenous } \\
\text { Cultures }\end{array}$ & Examples \\
\hline \multirow[t]{2}{*}{$\begin{array}{l}\text { Provide a different } \\
\text { cultural perspective } \\
\text { on wildlife }\end{array}$} & $\begin{array}{l}\text { 'Gives kids a whole new paradigm of looking at animals. } \\
\text { Spiritual aspect to it as most kids don't think about it } \\
\text { (e.g. how the cockatoo got its colours).' (non-Indigenous } \\
\text { manager) }\end{array}$ \\
\hline & $\begin{array}{l}\text { 'There is this big conflict with use of wildlife. Aboriginals } \\
\text { want to subsistence hunt and it is their right to do so. } \\
\text { Tourist value judgements are just one point on the } \\
\text { spectrum and Aboriginals have a different view - helping } \\
\text { them to understand this.' (non-Indigenous manager) }\end{array}$ \\
\hline $\begin{array}{l}\text { Break down cultural } \\
\text { barriers/stereotypes }\end{array}$ & $\begin{array}{l}\text { 'Need something to act as a link. Very valuable. Totems, } \\
\text { conservation and working towards that same end } \\
\text { lessens the differences and highlights the same goal.' } \\
\text { (non-Indigenous manager) }\end{array}$ \\
\hline \multirow[t]{4}{*}{$\begin{array}{l}\text { Indigenous relation- } \\
\text { ship to animals } \\
\text { (e.g. use, manage- } \\
\text { ment, respect, } \\
\text { spiritual) }\end{array}$} & $\begin{array}{l}\text { 'In some cases, for example, our tiger shark is our emblem, } \\
\text { our friend and no one here has been taken by a shark. We } \\
\text { are the only people that can hunt and kill turtle. We have } \\
\text { an understanding with wildlife: We respect them and } \\
\text { they respect us. As tourists learn about wildlife, they } \\
\text { learn about our culture.' (Indigenous manager) }\end{array}$ \\
\hline & $\begin{array}{l}\text { Brings to light the use of animals effectively. The interaction } \\
\text { between culture and wildlife are inseparable. Cannot } \\
\text { isolate them.' (non-Indigenous manager) }\end{array}$ \\
\hline & $\begin{array}{l}\text { 'Full understanding of animals more than before. Enlighten } \\
\text { them. Wildlife is closely associated with my culture. Totems } \\
\text { are animals and the spirit of a particular person or people } \\
\text { that once lived. Get sign from particular animal to tell them } \\
\text { of what is going to happen. Associate Aboriginal people } \\
\text { belonging to that species or spirits. '(Indigenous staff) }\end{array}$ \\
\hline & $\begin{array}{l}\text { 'I have a kangaroo cloak I made and wear it when present- } \\
\text { ing and talk how animal is so important to Aboriginals } \\
\text { and had respect for it, killed only for survival. Used in } \\
\text { ceremonies (e.g. initiation), food, medicine, not like white } \\
\text { people.' (Indigenous staff) }\end{array}$ \\
\hline \multirow[t]{2}{*}{$\begin{array}{l}\text { Better understanding } \\
\text { of Australian } \\
\text { wildlife }\end{array}$} & $\begin{array}{l}\text { 'A lot of people have the wrong perception of emus } \\
\text { (e.g. they think they are fierce). They are a very curious } \\
\text { bird. We catch birds and tourists pat them and get better } \\
\text { understanding of birds.' (Indigenous manager) }\end{array}$ \\
\hline & $\begin{array}{l}\text { 'Aboriginal dancing mimics the wildlife. When I am at the } \\
\text { zoo, I mimic the sound of brolgas and they come and } \\
\text { dance with me. I explain why Aboriginals mimic animals } \\
\text { (e.g. entice it for hunting) and pay respect in dancing and } \\
\text { ceremonies.' (Indigenous staff) }\end{array}$ \\
\hline $\begin{array}{l}\text { Benefit to Indigenous } \\
\text { people }\end{array}$ & $\begin{array}{l}\text { 'Helps to maintain traditional lifestyle for local people and } \\
\text { teach young kids. Wildlife is important as it allows them } \\
\text { to live traditional life.' (non-Indigenous manager) }\end{array}$ \\
\hline
\end{tabular}


Table 6 Tourist benefits from Aboriginal cultural interpretation of wildlife

\begin{tabular}{|c|c|}
\hline Tourist benefits & Examples \\
\hline $\begin{array}{l}\text { Gives value and worth } \\
\text { to wildlife } \\
\text { encounter }\end{array}$ & $\begin{array}{l}\text { 'Much better to hear about wildlife from Indigenous people. } \\
\text { It gives the experience a lot more credibility. More of a } \\
\text { feel of the place.' (non-Indigenous manager) }\end{array}$ \\
\hline \multirow[t]{2}{*}{$\begin{array}{l}\text { Benefits to Indigenous } \\
\text { peoples }\end{array}$} & $\begin{array}{l}\text { 'Pride for Aboriginal people - opportunity to explain their } \\
\text { culture.' (non-Indigenous manager) }\end{array}$ \\
\hline & $\begin{array}{l}\text { 'Does not reflect on Indigenous cultures unless have } \\
\text { Indigenous presenters providing the information on } \\
\text { culture.' (Indigenous staff) }\end{array}$ \\
\hline \multirow[t]{2}{*}{$\begin{array}{l}\text { Dispels myths/breaks } \\
\text { down stereotypes }\end{array}$} & $\begin{array}{l}\text { 'There are a variety of perspectives within the Aboriginal } \\
\text { community itself. Broadens the stereotypical idea that } \\
\text { Aboriginal people are into corroborees or eating kanga- } \\
\text { roos.' (non-Indigenous manager) }\end{array}$ \\
\hline & $\begin{array}{l}\text { 'Mostly they get the chance to talk to an Aboriginal person. } \\
\text { Ninety per cent probably had no involvement with } \\
\text { Aboriginal people. They really see how we have set it up. } \\
\text { Breaking down stereotypes.' (Indigenous manager) }\end{array}$ \\
\hline $\begin{array}{l}\text { Learning/education } \\
\text { about Indigenous } \\
\text { cultures }\end{array}$ & $\begin{array}{l}\text { 'Educated to our way of life and thinking, our history, } \\
\text { our law, how come here.' (Indigenous manager) }\end{array}$ \\
\hline $\begin{array}{l}\text { Positive attitude/ } \\
\text { respect for } \\
\text { Indigenous peoples }\end{array}$ & $\begin{array}{l}\text { 'Most develop positive attitudes toward Aboriginal people.' } \\
\text { (non-Indigenous manager) }\end{array}$ \\
\hline $\begin{array}{l}\text { Wildlife } \\
\text { use/understanding }\end{array}$ & $\begin{array}{l}\text { 'People think of animals as just an animal, but we try to put } \\
\text { animals in their environment (including the people).' } \\
\text { (non-Indigenous manager) }\end{array}$ \\
\hline $\begin{array}{l}\text { Awareness / } \\
\text { Understanding of } \\
\text { Indigenous cultures }\end{array}$ & $\begin{array}{l}\text { 'Get an understanding of Aboriginal culture and start to realise } \\
\text { what was here before European settlement (e.g. wildlife, } \\
\text { plants were used as food). We have lost our understanding } \\
\text { of the importance of plants and wildlife for our survival. } \\
\text { Gets us back to nature.' (non-Indigenous manager) }\end{array}$ \\
\hline $\begin{array}{l}\text { Meet tourist } \\
\text { expectations }\end{array}$ & $\begin{array}{l}\text { 'My clients are very keen to see Aboriginal culture and the } \\
\text { role of wildlife in it is pretty profound. Their expectations } \\
\text { are being met.' (non-Indigenous manager) }\end{array}$ \\
\hline
\end{tabular}

wildlife species by their tracks and use of animals or plants for food and medicine) from their own cultural knowledge and experience. The Indigenous respondents indicated they shared this wildlife and cultural information only if they felt confident and if it was information that they were culturally permitted to share with tourists.

At some attractions, managers and Indigenous staff differed in their viewpoint of the type and extent of Indigenous wildlife interpretation provided (see Tables 4 and 5). Indigenous staff focused on personal or family involvement with wildlife $(17 \%)$, traditional uses of wildlife $(17 \%)$ and creation stories 
about wildlife (15\%). Managers focused on traditional uses of wildlife (15\%), biological facts (14\%) and ecology (13\%). At one privately owned wildlife park, the manager responded that there was some Indigenous interpretation, but the Indigenous staff member interviewed felt that there was not enough information provided about Indigenous cultural knowledge and use of wildlife. Few wildlife sites interpreted Indigenous wildlife use issues, such as traditional hunting practices.

Table 4 summarises the specific kinds of interpretive information provided verbally about the wildlife in talks, demonstrations and in education programmes. The responses of the managers $(n=33)$ and Indigenous staff $(n=15)$ at the wildlife attractions are included together in Table 3 . The varied or multiple responses were evaluated according to key themes about wildlife interpretation. The interpretive information included biological facts, Aboriginal creation stories, traditional and contemporary wildlife use, conservation messages and personal involvement with wildlife. Indigenous staff presented traditional uses and personal stories about wildlife, including 'Dreaming' or creation stories, while non-Indigenous staff presented biological facts or species information about wildlife. This reflects different cultural perspectives on wildlife rather than conflicting messages delivered by staff or between Indigenous staff and non-Indigenous managers at different attractions. These interpretive messages highlight cultural differences with Indigenous moralistic (spiritual), utilitarian (food), and aesthetic (totems, symbolic significance) attitudes to wildlife in contrast to non-Indigenous ecologistic and scientistic attitudes to wildlife (Kellert, 1989, 1993; Lawrence, 1993). In addition, non-Indigenous people do not always have the cultural knowledge or permission to tell Indigenous stories about the spiritual meaning or totemic connections to wildlife.

Guides interpreted Indigenous knowledge and use of Australian wildlife mainly through formal presentations and also by informal discussion with the tourists. According to the managers, Indigenous guides mainly provided verbal interpretation through talks and within their education programmes for school groups, if requested. Aboriginal guides at Cleland Wildlife Park (SA) interpreted Dreaming stories of dingoes, emus, koalas and Yurrebilla, the Creation Ancestor on the Yurridla Aboriginal Trail (ARAZPA, 2002). There were also some captive sites that incorporated Dreamtime stories on their signage (e.g. Koala Dreaming Story at Western Plains Zoo, NSW) and/or included direct quotes from traditional elders on signs (e.g. Alice Springs Desert Park, NT; and Werribee Open Range Zoo, Victoria). One interpretive sign at Cleland Wildlife Park (SA) referred to Aboriginal wildlife knowledge and the cultural significance of endangered species, such as the yellow-footed rock wallaby or andu, as follows:

\section{Andu and the dreaming}

For many thousands of years Andu (Arndoo) has been significant to the dreamings of the Aboriginal people (Adnyamathantha community). Their dreamings and stories tell us that once bilbies, numbats, stick-nest rats, brush-tailed bettongs and other mammals inhabited the Flinders Ranges.

Other places interpreted the Indigenous component through regular dance performances for tourists that mimicked the movements of native wildlife, 
such as the kangaroo, emu and brolga (e.g. Currumbin Sanctuary, Billabong Sanctuary and Wild World Zoo, all in QLD). A few captive sites had specific Aboriginal cultural walking trails (e.g. Yurridla Trail at Cleland Wildlife Park, SA; Kangarrlta at Adelaide Zoo, SA; and Wurundjeri Dreaming at Healesville Sanctuary, Victoria) mainly used for school programmes. Some wildlife sites, then, specifically added the Indigenous cultural element through Aboriginal guided tours, dance performances or interpretive signage, while with others it featured only incidentally as a part of other wildlife talks.

\section{Aboriginal cultural interpretation of wildlife}

The source of this Indigenous cultural information about wildlife, according to the managers and owners, generally seemed to come from the managers' experience or their own personal research (e.g. consulting with the local Indigenous community and reading books) as well as directly from the local Indigenous people. For the most part, this cultural information about Australian wildlife was gathered verbally from the local Indigenous people and then written down. Moreover, the wildlife interpretation provided by Indigenous guides was usually at a more 'spiritual' level (e.g. Dreaming or creation stories; and relationship to animals and the land) than talks given by non-Indigenous guides. Indigenous guides also used visual aids such as artefacts (e.g. boomerangs, traps, fishing nets, spears, clubs, shield and baskets) to provide this cultural information. The employment of Indigenous people as guides to specifically provide this cultural information is more common at wildlife parks in northern and central Australia. At other wildlife sites in this study all staff (regardless of whether they are Indigenous or not) included a cultural component in their wildlife talks and presentations, mainly traditional hunting and 'Dreamtime' stories about wildlife.

Some examples of how Aboriginal cultural interpretation of wildlife was incorporated within the overall tourism program are illustrated in the following quotes recorded from managers:

Through presentations by park guides on how Aboriginal people utilise wildlife and how Aboriginals interpret the seasons. Wildlife use, totems and dreaming. There are odd bits on signs, but minimal which I want to address. There is the odd point made in keeper talks, where possible, it is up to the individual. (non-Indigenous manager)

Done verbally. Point out sea eagles. All do it. Their way of understanding animals. And through dances. (Indigenous manager)

The Indigenous staff members reported that the source of the cultural information was from their own experiences (e.g. training from elders on how to hunt), from family members or from speaking with local elders and traditional owners. The stories have usually been passed down from other family members or senior elders in the community. As one Indigenous manager/owner remarked, the importance of respecting this cultural knowledge and not telling stories without appropriate permission is reflected in the following quote: 'Practicing of law in community is very strong so you know what you can say and what you can't.' A few respondents also cited having acquired their cultural and 
wildlife knowledge through their tertiary studies in tour guiding (e.g. Tauondi College, SA). The following quotations from Indigenous staff explain how they use their Indigenous cultural knowledge in wildlife interpretation:

Share with them what we do here: How hunt; bush tucker; some ceremonies; important stories about the land and wildlife; dancing (the younger people; I am too old to dance now). I do not talk about totems or sacred sites as this is only for old people ('culture people').

... the source of Indigenous knowledge is through me from stories passed down through the generations. It is all done verbally (orally) - no written information provided to the tourists. My mother gave me permission to include Dreamtime stories on a CD, but not in a book because the Aboriginal culture is an oral (not written) one.

The information is presented verbally by the guides. The source of the knowledge is from my own experience, by talking with the National Parks and Wildlife (my Uncle works there) and my Auntie who is an archaeologist as well as speaking with the elders (I can't talk about sacred men's and women's business with tourists).

Through the information provided verbally by guides like me. This is the Aboriginal way. Did not have books. Dreaming stories of wildlife. Learn by listening.

Managers and Indigenous staff also provided additional information about the way that Indigenous cultures are presented at their wildlife attraction or operation:

- cultural information presented on the signage and maps (and sculptures at the Australian wildlife area);

- giving Indigenous names to some of the newborn wildlife: 'Twin baby platypuses were given Aboriginal names with ceremony during the day... Set spirit free in smoking ceremony when one died';

- cultural demonstrations (e.g. fire lighting when talking about food source, boomerang and didgeridoo);

- cultural content within talks and guided tours (e.g. 'Dreamtime' stories and visiting sites of significance).

Overall, this study found there was a greater emphasis on interpreting Indigenous cultural practices (not wildlife specific) rather than on Indigenous knowledge and use of Australian wildlife (Muloin et al., 2001; Zeppel \& Muloin, 2005). The emphasis on general cultural practices may reflect a dilution of detailed Indigenous knowledge about specific wildlife species or reluctance to present this in tours.

\section{Benefits of Aboriginal Wildlife Interpretation: Results}

Respondents stated how Australian wildlife could help tourists understand Indigenous cultures. In total, 28 of the 33 managers interviewed (85\%) felt that Indigenous interpretation of wildlife could be used to help tourists to better understand or appreciate Australian Indigenous cultures. Of the 15 Indigenous 
staff interviewed, 12 felt that wildlife helped tourists to understand Indigenous cultures (80\%), while two replied 'no' (13\%). Respondents elaborated on how wildlife is used in helping tourists to understand or appreciate Australian Indigenous cultures. Offering a different cultural perspective about wildlife and discussing the relationship between Indigenous people and wildlife were the two most frequently cited responses by managers (see Table 5). For Indigenous staff, the most widely cited response was the cultural relationship between Indigenous people and wildlife. This was often illustrated in their response by providing specific examples of Indigenous cultural interactions with wildlife. A few staff also cited the importance of the presenter needing to be Indigenous. One manager indicated that the provision of Indigenous cultural information was dependent upon the respective guide and how comfortable they were in interpreting Indigenous culture (if non-Indigenous) or presenting information about a cultural group not their own (if Indigenous). Indigenous staff also noted the use of Aboriginal dance performances and tourist excitement at meeting Indigenous people derived from the novelty of seeing and interacting with Indigenous cultures (e.g. Moscardo \& Pearce, 1999). However, Indigenous staff members did not mention the following benefits cited by managers: providing a different perspective on wildlife; breaking down cultural barriers; interaction with an Indigenous person; better understanding of Australian fauna; and the benefits of wildlife tourism to Indigenous people.

One open-ended question to all respondents asked what they thought the benefits to tourists were from including Indigenous cultural content at wildlife attractions. The most common response cited by managers was learning or gaining knowledge about Indigenous cultures and wildlife as well as building general awareness and understanding of Indigenous cultures (see Table 6).

Indigenous staff also frequently cited education/learning by tourists about Indigenous cultures as a very important benefit of wildlife tourism. Indigenous staff members often provided responses about tourist opportunities for education and learning that were specific to the wildlife site, the types of wildlife interpretation provided or cultural content given to tourists. Further, in contrast to managers, Indigenous staff members did not cite or seem to recognise Indigenous content as giving additional value or worth; a better understanding of wildlife; or social benefits to Indigenous people from wildlife tourism. However, one social benefit was that Indigenous staff recognised that they provided a role model for other Indigenous people interested in working at wildlife attractions or in the wider tourism industry.

Comments made by Indigenous staff on developing Indigenous wildlife interpretation were as follows:

More signage about animals (including Aboriginal names).

Would like to see more Aboriginal people doing tours so give a better impression and learn about their culture (for international tourists).... A better respect for Aboriginal people.

Would like to see local language people involved as they are the ones that can tell the stories about their area and can say words properly. 
The most common opportunity for Indigenous involvement in wildlife tourism cited by both managers and Indigenous staff was providing more Indigenous interpretation of wildlife and the natural environment to tourists and school groups as 'cultural guides' or educators. The Alice Springs Desert Park (NT) has implemented strategies for Aboriginal people to develop and deliver park interpretation and to expand the Aboriginal content in the Park (ASDP, 2001). Indigenous staff also mentioned greater self-esteem or empowerment resulting from employment opportunities in the wildlife tourism industry. The benefits of Indigenous people providing cultural interpretation at Australian wildlife attractions included the following:

There is a lot to be gleaned before it disappears; useful to wildlife preservation and understanding. Rich aspect of tourism and can only improve the quality of the tourist experience. [non-Indigenous manager]

Wildlife tourism and cultural tourism are tied together. The whole thing from ownership, management, guiding and administration. [Indigenous manager]

Indigenous staff viewed wildlife interpretation as a cultural and employment opportunity while managers found Indigenous wildlife knowledge in signs and tours added to the tourist experience.

\section{Guidelines for Aboriginal Wildlife Interpretation}

The research findings of this study and other evaluations of Indigenous cultural interpretation (Ballantyne, 1995; Miller, 1996; Interpretation Australia, 2003) provide a preliminary indication of some key guidelines to enhance and further develop Aboriginal interpretation at wildlife attractions (see Table 7). These suggested guidelines relate to verbal and written forms of Aboriginal wildlife interpretation. This study indicates there are significant opportunities to include or further develop Aboriginal cultural interpretation at Australian wildlife attractions. For example, how many visitors learn that kangaroo, koala and kookaburra are all Aboriginal names? Or that Indigenous relationships with Australian wildlife species includes totemic or spiritual affiliations, subsistence and commercial uses of wildlife as well as contemporary wildlife

Table 7 Some guidelines for Aboriginal cultural interpretation of wildlife

- Employ local Indigenous guides/wildlife keepers at wildlife attractions.

- Use selected local Aboriginal names for Australian wildlife species (where known).

- Identify the Aboriginal name (language group) of well-known Australian animals (e.g. kangaroo, koala and kookaburra).

- Include quotes and stories from local Aboriginal people about Australian wildlife.

- Refer to Aboriginal guides who accompanied historic or recent wildlife expeditions.

- Acknowledge Aboriginal totemic/spiritual links with Australian wildlife (beyond 'Dreamtime' stories about wildlife) like Aboriginal custodians of wildlife species.

- Contrast Indigenous and non-Indigenous perspectives of Australian wildlife (e.g. wildlife as an Indigenous food resource versus wildlife viewing by tourists).

- Describe Aboriginal involvement in contemporary Australian wildlife management (e.g. fauna surveys, wildlife research, endangered species, hunting, wildlife farms)

- Interpret contentious issues in Indigenous wildlife use (e.g. traditional hunting).

- Develop policies on Indigenous cultural interpretation at captive wildlife attractions. 
management? Indigenous perspectives on wildlife are a unique part of Australia's cultural heritage. This Indigenous wildlife knowledge can add value and cultural diversity to wildlife attractions and the tourism industry in Australia (Howard et al., 2001; Pitcher et al., 1999; Zeppel \& Muloin, 2005; Zeppel et al., 2003). However, this Aboriginal wildlife knowledge must be presented in culturally appropriate ways.

The responses of 35 managers (nine Indigenous) and 26 Indigenous staff at wildlife attractions and tour operations interviewed for this study suggest that future research on Indigenous cultural interpretation at wildlife attractions and sites could include the following:

- Review Indigenous input and content of signs, displays and brochures at wildlife attractions.

- Survey tourist interest in and demand for Indigenous cultural interpretation at wildlife sites.

- Compare Indigenous and non-Indigenous presentations and methods of wildlife interpretation.

- Record and interpret local Indigenous knowledge, use and management of wildlife species.

- Explore difficulties in interpreting Indigenous wildlife knowledge and practices (e.g. hunting).

- Examine Indigenous interpretations of wildlife at zoos and wildlife sites in other countries.

Australian wildlife attractions do not interpret difficult issues such as Indigenous people hunting and killing endangered wildlife species, such as turtle and dugong (Birtles et al., 2004; Department of Environment and Heritage, 2005; Hinch, 1998; Schmiechen, 2006; Walker, 2003), Indigenous hunting of kangaroos (Zeppel, 1998; Howard et al., 2001) nor the licensed culling of kangaroos for pet meat and human consumption by non-Indigenous shooters (Davies et al., 1999; Thorne, 1998). Within Indigenous wildlife tourism the continued subsistence hunting of dugong and marine turtles and harvesting turtle eggs in northern Australia can also conflict with tourist viewing of marine wildlife and western conservation ethics. On Melville Island, north of Darwin (NT), Tiwi Aboriginal people considered dugong watching as a tourist activity, however no clan groups wanted to close their own hunting areas as a sanctuary. At Putjamirra Lodge, in the late 1980s Tiwi people decided not to hunt dugong in the immediate tourist area offshore but the lodge subsequently closed.

Controversial issues in wildlife conservation also need to be interpreted to zoo visitors (Hopgood, 2000; Swanagan, 2000). Disney's Animal Kingdom in the United States includes interpretive signs and keeper presentations about the impact of the bushmeat trade in Africa on wildlife (Lehnhardt et al., 2004). At Taronga Zoo in Melbourne, a graphic sign shows a woman in a fur coat with a skinned snow leopard below, often defaced with the word 'bitch' on the sign or prompting letters from zoo visitors (Cook, 1999). Human-wildlife conflicts and the ongoing use of wildlife for food and ceremonies were interpreted for other cultures and countries, such as Asia and Africa, but not for Indigenous relationships with and use of native wildlife in Australia. This Indigenous cultural content is also often an 'add-on' aspect of species interpretation at wildlife sites. The new 'Platypusary' habitat exhibit in Healesville Sanctuary 
(Melbourne, Victoria) includes an Indigenous voice but this was not integrated with the key themes of waterway protection and staff as conservation role models. The Jurabi Turtle Centre in Exmouth (WA) plans to include Indigenous stories along pathways to turtle nesting beaches, yet Indigenous perspectives were not integrated with marine turtle conservation messages on current interpretive panels (Interpreting Australia, 2005). In contrast, at Mutton Bird Island Nature Reserve in Coffs Harbour (NSW) a Gumbaynggir Aboriginal ranger interprets the cultural significance of this men's site and the former harvesting of wedge-tailed shearwaters on guided tours held each month from September to April (Walton et al., 2006).

\section{Conclusion}

Aboriginal interpretation of Australian wildlife can enrich visitor experiences of wildlife and contribute to greater awareness and understanding of Indigenous Australian cultures. This study suggests Aboriginal wildlife interpretation can be enhanced by employing Indigenous guides and by developing signs, displays and brochures that interpret Indigenous cultural knowledge of wildlife. These unique Indigenous perspectives of Australian wildlife can add a new cultural dimension to captive wildlife attractions and other wildlife tourism operations in Australia. The responses in this study highlight key cultural differences in animal attitudes and approaches to wildlife interpretation. Indigenous staff verbally presented traditional uses and personal stories about wildlife along with Aboriginal 'Dreaming' or creation stories about totemic animal species. Non-Indigenous staff explained Aboriginal uses of wildlife along with biological facts and species information. These interpretive messages reflect Indigenous moralistic (spiritual), utilitarian (food), and aesthetic (totems, symbolic significance) attitudes to wildlife in contrast to non-Indigenous ecologistic and scientistic attitudes to wildlife. Indigenous cultural input at wildlife sites, then, has the potential to expand and alter visitor understandings of Australian wildlife. This study found that some wildlife attractions are adding an Aboriginal theme (i.e. artwork, dances, 'Dreamtime' stories and wildlife names) to current wildlife displays, yet few interpretive signs or programmes recognise and present Aboriginal cultural knowledge, use and management of wildlife. Non-Indigenous wildlife interpretation mainly focuses on biological science and conservation rather than cultural or social aspects of animal interactions. The perceived difficulties of incorporating Indigenous cultural values in wildlife interpretation and a lack of Indigenous employment or cultural policies at wildlife attractions also limit the potential for Aboriginal cultural interpretation in Australian wildlife tourism.

\section{Correspondence}

Any correspondence should be directed to Heather Zeppel, Tourism Program, School of Business, James Cook University, P.O. Box 6811, Cairns, Qld, 4870, Australia (heather.zeppel@jcu.edu.au).

\section{Acknowledgements}

This project was completed with funding provided by the Cooperative Research Centre for Sustainable Tourism. The authors thank Professor Marcia 
Langton, Dr Karen Higginbottom and the staff members at Australian wildlife attractions and tours that sent resource materials and participated in this study of Indigenous wildlife tourism.

\section{References}

Adams, L. (1996) Aboriginal perspectives and the environment. Journal of the International Zoo Educators Association 33, 28.

Alice Springs Desert Park (ASDP) (2001) Alice Springs Desert Park Long Term Plan 2001-2006. Alice Springs: ASDP.

Alice Springs Desert Park (ASDP) (2004) Aboriginal Interpretation. Alice Springs Desert Park Website. On WWW at http:/ / www.alicespringsdesertpark.com.au/aboriginal. html. Accessed 25/7/06.

ARAZPA (2002) Yurridla Aboriginal Trail. Education Policy Support Documents. On WWW at http:/ / www.arazpa.org.au/Education_Oncom_Yurridla.htm Accessed $25 / 7 / 06$.

Aughterson, J. (2004) Multimedia interactives within 'Trial of the Elephants'. Journal of the International Zoo Educators Association 39, 24-25.

AWMS (Australasian Wildlife Management Society) (2004) AWMS Position on Use of Wildlife by Indigenous People. On WWW at http://www.awms.org.nz/ positionstatements/indiguse.html. Accessed 25/7/06.

Baker, L. (1996) Mingkiri: A Natural History of Uluru by the Mutitjulu Community. Alice Springs: IAD Press.

Ballantyne, R. (1995) Interpreter's conceptions of Australian Aboriginal culture: Implications for interpretive practice. The Journal of Environmental Education 26 (4), 11-17.

Birtles, A., Curnock, M., Dobbs, K., Smyth, D., Marsh, H., Arnold, P., Valentine, P., Limpus, C., Hodgson, A., Pierce, S., Taverner, M., Barr, R. and Millers, D. (2004) Cultural information for sustainable management. In Towards Sustainable Dugong and Turtle Tourism: The Key Issues. Draft issues paper 13 May 2004. On WWW at http:// www.dugongturtletourism.org/ Accessed 25/7/06.

Bomford, M. and Caughley, J. (eds) (1996) Sustainable Use of Wildlife by Aboriginal Peoples and Torres Strait Islanders. Bureau of Resource Sciences. Canberra: AGPS.

Broad, S. and Weiler, B. (1998) Captive animals and interpretation: A tale of two tiger exhibits. The Journal of Tourism Studies 9 (1), 14-27.

Carr, A. (2004) Mountain places, cultural spaces: The interpretation of culturally significant landscapes. Journal of Sustainable Tourism 12 (5), 432-459.

Clarkson, J. (1999) Consulting with local Aboriginal people about cultural interpretation. In Proceedings of the 1999 ARAZPA/ASZK Annual Conference. Alice Springs, NT: Alice Springs Desert Park, 15-19.

Commonwealth of Australia (1998) Hunting and Indigenous use of wildlife. In Commercial Utilisation of Australian Native Wildlife (pp. 363-394). Report of the Senate Rural and Regional Affairs and Transport References Committee, June 1998. Canberra, ACT: Commonwealth of Australia.

Cook, E. (1999) Being a zoo designer: Achievements and challenges. In The Human Factor in Interpretation (pp. 37-41). Collingwood, Vic: Interpretation Australia Association.

Davies, J. (1999) Of caribou and kangaroos: Agreements about wildlife. Indigenous Law Bulletin 4 (21), 27-29.

Davies, J., Higginbottom, K., Noack, D., Ross, H. and Young, E. (1999) Sustaining Eden: Indigenous Community Wildife Management in Australia. Evaluating Eden Series No. 1. London: International Institute for Environment and Development.

Department of the Environment and Heritage (DEH) (2005) Sustainable Harvest of Marine Turtles and Dugongs in Australia - A National Partnership Approach. November 2005. Canberra: DEH. On WWW at http://www.deh.gov.au/coasts/species/turtles/ national-approach.html. Accessed 25/7/06.

Department of Industry, Tourism and Resources (2004) Demand for Nature-Based and Indigenous Tourism Product. Canberra: Department of Industry, Tourism and Resources. OnWWWathttp://www.industry.gov.au/assets/documents/itrinternet/2_Executive_ Summary20041110114758.pdf. Acessed 25/7/06. 
Green, E.S. (1993) Gender, politics and spiritual transformation: Comment on Lawrence. Society \& Animals 1 (1), 39-44.

Hills, A.M. (1993) The motivational bases of attitudes toward animals. Society $\mathcal{E}$ Animals 1 (2), 111-128.

Hinch, T. (1998). Ecotourists and Indigenous hosts: Diverging views on their relationship with nature. Current Issues in Tourism 1 (1), 120-124.

Hopgood, J. (2000) Zoo education - should the focus be biological science and zoo animals? Journal of the International Zoo Educators Association 36, 6-9.

Howard. J., Thwaites, R. and Smith, B. (2001) Investigating the roles of the indigenous tour guide. The Journal of Tourism Studies 12 (2), 32-39.

Interpretation Australia (IA) (2003) Best Practice for Interpreting Aboriginal Culture and Country. The IAA Guidelines. On WWW at http://www.interpretationaustralia.asn. au/infofiles/IAA_guidelines.pdf. Accessed 25/7/06.

Interpreting Australia (2005) National IAA awards for excellence in heritage interpretation 2005. Interpreting Australia 31/32, 5.

Kellert, S.R. (1989) Perceptions of animals in America. In R.J. Hoage (ed.) Perceptions of Animals in American Culture. Washington DC: Smithsonian Institution Press.

Kellert, S.R. (1993) The biological basis for human values of nature. In S.R. Kellert and E.O. Wilson (eds) The Biophilia Hypothesis. Washington DC \& Covelo, CA: Island Press \& Shearwater Books.

Langton, M. (1998) Burning Questions: Emerging Environmental Issues for Indigenous Peoples in Northern Australia. Darwin, NT: Centre for Indigenous Natural \& Cultural Resource Management, Northern Territory University.

Lawrence, E.A. (1993) The symbolic role of animals in the Plains Indian sun dance. Society and Animals 1 (1), 17-37.

Lehnhardt, K., Hauck, D., Wilson, S., Sellin, R., Kuhar, C. and Miller, L. (2004) Assessment of the bushmeat message at Disney's Animal Kingdom. Journal of the International Zoo Educator's Association 40, 22-25.

Mason, P. (2000) Zoo tourism: The need for more research. Journal of Sustainable Tourism $8(4), 333-339$.

Meek, P. and O'Brien, P. (1992) Wildlife Use and Management: Report of a Workshop for Aboriginal and Torres Strait Islander People. Bureau of Rural Resources Report No. R/2/92. Canberra: Australian Government Publishing Service.

Miller, G. (1996) Indigenous tourism - A Queensland perspective. In H. Richins, J. Richardson and A. Crabtree (eds) Ecotourism and Nature-based Tourism: Taking the Next Steps (pp. 45-57). Brisbane: Ecotourism Association of Australia.

Moscardo, G.M. and Pearce, P.L. (1999) Understanding ethnic tourists. Annals of Tourism Research 26 (2), 416-434.

Muloin, S., Zeppel, H. and Higginbottom, K. (2001) Indigenous Wildlife Tourism in Australia: Wildlife Attractions, Cultural Interpretation and Indigenous Involvement. Wildlife Tourism Research Report Series: No. 15. Gold Coast, Qld: CRC for Sustainable Tourism. On WWW at http:/ / www.crctourism.com.au/CRCBookshop/Documents/ FactSheets/ENV0015Indigenous\%20.pdf. Accessed 25/7/06.

Palmer, L. (2001) Indigenous Interests in Hunting and Fishing Tourism in the Northern Territory: Assessment of Key Issues. Wildlife Tourism Research Report Series: No. 8. Gold Coast: CRC for Sustainable Tourism, \& Darwin: Centre for Indigenous Natural \& Cultural Resource Management, Northern Territory University. On WWW at http://www. crctourism.com.au/CRCBookshop/Documents/FactSheets/ENV0008Safari\%20. pdf. Accessed 25/7/06.

Peters, C. (2002) Trailing Chief Black Bison - an event for children at Rotterdam Zoo. Journal of the International Association of Zoo Educators 38, 11-12.

Pitcher, M., van Oosterzee, P. and Palmer, L. (1999) 'Choice and Control': The Development of Indigenous Tourism in Australia. Darwin, NT: Centre for Indigenous Natural and Cultural Resource Management, Northern Territory University \& CRC for Sustainable Tourism.

Podhorska, I.E. (2004) Zookeeper's specialist potential in public conservation education. Journal of the International Zoo Educators Association, 40, 10.

Povey, K.D. and Rios, J. (2002) Using interpretive animals to deliver affective messages in zoos. Journal of Interpretation Research 7 (2), 19-28. 
Ramsay, B.J. (1994) Commercial Use of Wild Animals in Australia. Canberra: AGPS.

Ris, M. (1994) Why look at whales? Reflections on the meaning of whale watching. In 11 Essays on Whales and Man (2nd edn). High North Publication. On WWW at http:/ / www.highnorth.no/Library/Watching/wh-lo-at.htm. Accessed 25/7/06.

Schmiechen, J. (2006) See em or eat em! Indigenous wildlife tourism - where is it at? In Getting Real About Wildlife Tourism: Conference Program (p. 68). The 2nd Australian Wildlife Tourism Conference, 13-15 August 2006, Fremantle, Western Australia. Promaco Conventions, Canning Bridge, WA.

Shackley, M. (1996) Wildlife in captivity. In Wildlife Tourism (pp. 97-118). London: International Thomson Business Press.

Slotta-Bachmayr, L. (2003) Animals and culture - raising interest in animals by highlighting their cultural significance. Journal of the International Zoo Educators Association 39, $14-15$.

Smith, L. and Broad, S. (2006) Examining the role of zoos in conservation education. In G.B. O'Mahoney and P.A. Whitelaw (eds) CAUTHE Conference "To the City and Beyond..." Proceedings of the 16th Annual CAUTHE Conference, Victoria University, Melbourne, 1344-1348.

Swanagan, J.S. (2000) Factors influencing zoo visitors' conservation attitudes and behavior. The Journal of Environmental Education 31 (4), 26-31.

Thorne, L. (1998) Kangaroos: The non issue. Society \& Animals 6 (2), 167-182.

Tribe, A. (2001) Captive Wildlife Tourism in Australia. Gold Coast, Qld: CRC for Sustainable Tourism. On WWW athttp:/ / www.crctourism.com.au/CRCBookshop/Documents/ FactSheets $/ 14 \% 20$ Captive\%20wildlife.pdf. Accessed 25/7/06.

Tribe, A. (2004) Zoo tourism. In K. Higginbottom (ed.) Wildlife Tourism: Impacts, Management and Planning (pp. 35-56). Altona, Vic: Common Ground Publishing \& Sustainable Tourism CRC.

Walker, L. (2003) Case Study - Turtle and Dugong Hunting Management in Far North Queensland. Resource 8 in Module 14: Multicultural Perspectives: Indigenous People. Coasts and Marine Schools Project. Marine Education Society of Australasia Inc. On WWW at http://www.mesa.edu.au/cams/module14/resources01.htm\#res8. Accessed 25/7/06.

Walton, A., Flanders, M. and Cooper, K. (2006) Wildlife tourism - an opportunity for conservation management outcomes and Aboriginal cultural heritage recognition. In Getting Real About Wildlife Tourism: Conference Program (pp. 197-206). The 2nd Australian Wildlife Tourism Conference, 13-15 August 2006, Fremantle, Western Australia. Promaco Conventions, Canning Bridge, WA.

Wilson, G., McNee, A. and Platts, P. (1992) Wild Animal Resources: Their Use by Aboriginal Communities. Bureau of Rural Resources. Canberra: AGPS.

Wilson, C. and Tisdell, C. (2001) Sea turtles as a non-consumptive tourism resource especially in Australia. Tourism Management 22 (3), 279-288.

Woods, B. (1998) Animals on display: Principles for interpreting captive wildlife. The Journal of Tourism Studies 9 (1), 28-39.

Yibarbuk, D. (1998) Introductory essay: Notes on traditional use of fire on upper Cadell River. In M. Langton (ed.) Burning Questions: Emerging Environmental Issues for Indigenous Peoples in Northern Australia (pp. 1- 6). Darwin: Centre for Indigenous Natural \& Cultural Resource Management, NTU.

Zeppel, H. (1998) Selling the Dreamtime: Aboriginal culture in Australian tourism. In D. Rowe and G. Lawrence (eds) Leisure, Tourism, Sport: Critical Perspectives (pp. 23-38). Sydney: Hodder Headline.

Zeppel, H. and Muloin, S. (2005) Indigenous interpretation of Australian wildlife: Cultural values in tourism operations. In P. Tremblay and A. Boyle (eds) Sharing Tourism Knowledge: Proceedings of the 2005 CAUTHE Conference (CD-ROM) Darwin, NT: Charles Darwin University.

Zeppel, H., Muloin, S. and Higginbottom, K. (2003) Kangaroo or gangurru? Indigenous wildlife interpretation in Australia. In R. Black and B. Weiler (eds) Interpreting the Land Down Under: Australian Heritage Interpretation and Tour Guiding (pp. 165-185). Golden, CO: Fulcrum. 